\title{
Long-term changes of the crustacean zooplankton community in Lake Mjøsa, the largest lake in Norway
}

\author{
Jarl Eivind LØVIK* and Gösta KJELLBERG \\ Norwegian Institute for Water Research, Branch Office East, N-2312 Ottestad, Norway \\ *e-mail corresponding author: jarl.loevik@niva.no
}

\begin{abstract}
Lake Mjøsa has been subject to an accelerating eutrophication from the 1950s to the mid 1970s, but comprehensive nutrient reduction efforts caused marked reductions of phytoplankton production and biomass during the 1980s, a process that continued during the 1990s. Zooplankton biomass and species composition was considerably affected during the eutrophication and subsequent oligotrophication. Total crustacean zooplankton biomass decreased along with decreasing algal biomass during the 1980s and 1990s. The seasonal means of zooplankton biomass were positively correlated with seasonal means of phytoplankton biovolume and chlorophyll-a, indicating a primarily bottom up regulation of the zooplankton biomass. Several herbivorous and omnivorous zooplankton species (Daphnia galeata, Bosmina longispina, Limnocalanus macrurus and Cyclops lacustris) were probably negatively affected by reduced algal biomass, whereas other species (Holopedium gibberum and Thermocyclops oithonoides/Mesocyclops leuckarti) seemed to be positively affected. H. gibberum disappeared in the 1960s, but reappeared in the 1980s after the significant reduction in algal biomass and primary production. The temporal trend of $\mathrm{T}$. oithonoides/M. leuckarti indicated a strong competition with cladocerans (mainly B. longispina and D. galeata) in periods with high algal biomass. Early warming of the lake could also have promoted a biomass increase of $\mathrm{T}$. oithonoides/M. leuckarti in later years, although the mean epilimnion temperature did not correlate with seasonal mean biomass of these species. The seasonal mean biomass of Eudiaptomus gracilis, the dominant calanoid, showed substantial fluctuations with 6-7 years between tops, but a decreasing trend during the 1990s. However, there were no significant correlations between this species and any of the environmental variables. The study indicated that dominant cladocerans (D. galeata and $\mathrm{B}$. longispina) are decisive for the success of cisco (Coregonus albula), one of the most important planktivorous fish species, as also described by earlier studies. However it also demonstrated top down control on cladocerans in years with especially large stocks of cisco.
\end{abstract}

Key words: Lake Mjøsa, zooplankton, temporal changes, eutrophication, oligotrophication

\section{INTRODUCTION}

Species composition and biomass of phytoplankton and zooplankton as well as population characteristics of single species represent important inputs when studying effects of more or less man-made environmental changes of lake ecosystems (Schindler 1987). Thus, long-term data series on plankton and environmental variables are growing steadily more valuable for each year added. Phytoplankton, crustacean zooplankton and environmental variables have been monitored in Mjøsa, the largest lake in Norway, since 1972. The lake serves as drinking water reservoir for approximately 80,000 individuals and has great importance for recreation and fishing activities, as well as for agricultural irrigation purposes and recipient for sewage treatment plants.

At the beginning of the $20^{\text {th }}$ century Lake Mjøsa was oligotrophic (Huitfeldt-Kaas 1906), but as in many other lakes in Norway an accelerating eutrophication took place from the 1950s, caused by increasing nutrient loading from agriculture, domestic wastewater and industries (Holtan 1979). The first severe actions to reduce nutrient inputs were taken in 1973, but the eutrophication continued and culminated in 1976 with a vigorous growth of cyanophytes. As a consequence of this event and increasing attention to the massive water quality problems from the public, limnologists, authorities and politicians a comprehensive nutrient reduction program was established in 1977 ("Save Mjøsa Campaign" 1977-1981). In the following years high priority was given to building of sewage pipe lines and municipal treatment plants, and new restrictions were introduced in order to reduce discharges from agriculture and industries. The nutrient reduction actions led to a nearly extinction of cyanophytes and marked reductions of primary production and phytoplankton biomass during the 1980s (Rognerud \& Kjellberg 1990; Holtan 1993). The long-term oligotrophication process continued during the 1990s and caused increased transparency and nearly acceptable water quality in the lake (Kjellberg et al. 2001), although considerable autumn blooms of diatoms have been observed even in recent years.

Studies from other large lakes like Bodensee, Lake Washington, Lago Maggiore and Lake Mälaren have shown that temporal changes in trophic state have been accompanied by important changes in the zooplankton communities (Einsle 1978; Edmondson \& Litt 1982; Manca \& Ruggio 1998; Wallin et al. 2000). The aim of this study is to present zooplankton data from Lake Mjøsa for the period 1972-2000, and to examine the 


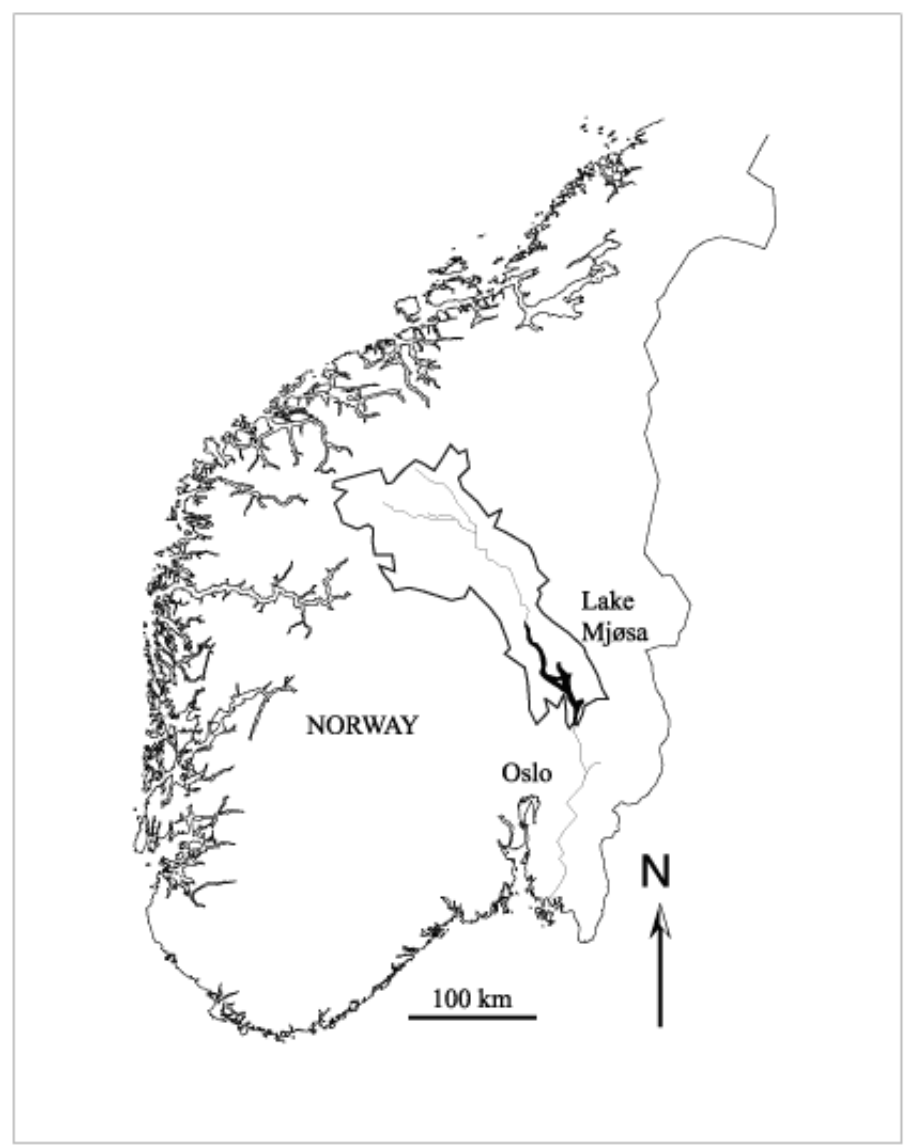

Fig. 1. Location of Lake Mjøsa and its catchment in South Norway.

temporal change in the crustacean biomass and species composition in the light of changes in abiotic and biotic factors like water temperature, phytoplankton biomass and planktivorous fish.

\section{STUDY SITE}

Lake Mjøsa is a deep fjord lake (max depth $453 \mathrm{~m}$ ) situated in Southeast Norway (Fig. 1). The surface area is $362 \mathrm{~km}^{2}$, mean depth $153 \mathrm{~m}$, and the theoretical residence time 5.6 years. Large parts of the catchment area consist of mountain regions. Several glaciers in this region feed the main tributary with heavy silt load during June-August. The water flow from the river causes reductions in transparency, temperature and algal growth in Lake Mjøsa during early summer, especially in the northern parts of the lake (Holtan 1979). The lowland areas around the central part of the lake are one of Norway's best agricultural districts. The total population in the catchment area is $c a 200,000$, of which about 150,000 live in the immediate surroundings of the lake. Implementation of the nutrient reduction plans have caused $\mathrm{ca} 50 \%$ decrease in total phosphorus concentration (seasonal means, $0-10 \mathrm{~m}$ layer) in the lake from 10 $\mu \mathrm{g} \mathrm{l^{-1 }}$ in the late $1970 \mathrm{~s}$ to $5 \mu \mathrm{g} \mathrm{l}^{-1}$ at the turn of the century (Kjellberg et al. 2001). Total nitrogen concentra- tion increased by ca $50 \%\left(160 \mu \mathrm{g}^{-1}\right)$ during the $1970 \mathrm{~s}$ and 1980s. However, no further increase took place during the 1990s. Mjøsa is used as a reservoir for hydroelectric power production, and the draw down zone is $3.6 \mathrm{~m}$. Cisco (Coregonus albula), smelt (Osmerus eperlanus) and whitefish (Coregonus lavaretus) are the most important planktivorous fish species in Lake Mjøsa (Kjellberg \& Sandlund 1983). Some limnological characters for the study period from 1972 to 2000 are given in table 1. Further information on the lake and the catchment is given by Holtan $(1979,1993)$ and Kjellberg et al. (2001).

\section{METHODS}

Samples were collected fortnightly from June $1^{\text {st }}$ to October $31^{\text {st }}$, but in some years only monthly sampling were performed. Data presented here are from the main station (centre of the lake) at the deepest part of the lake from the period 1972-2000. Zooplankton was not sampled in 1975 and only once a year in 1976 and 1977. These observations are therefore not used in calculations of seasonal means. The zooplankton samples were collected with a 25-1 Schindler-trap from 0.5, 2, 5, 8, 12, $16,20,30$ and $50 \mathrm{~m}$. The crustacean plankton individuals of each sample were counted and the biomass (ZB) 
Tab. 1. Limnological characteristics of Lake Mjøsa (main station, 1972-2000).

\begin{tabular}{|c|c|c|c|c|c|c|}
\hline Variable & mean & SD & $\min$ & median & $\max$ & $\mathrm{N}$ \\
\hline Epilimnion temp $\left({ }^{\circ} \mathrm{C}\right)$ & 11,5 & 3,0 & 4,0 & 12,0 & 19,6 & 265 \\
\hline Transparency $(\mathrm{m})$ & 7,4 & 2,2 & 2,6 & 7,3 & 15,5 & 269 \\
\hline Total phosphorus $\left(\mu \mathrm{g} \mathrm{l}^{-1}\right)$ & 7,7 & 2,8 & 2,0 & 7,3 & 16,0 & 254 \\
\hline Total nitrogen $\left(\mu \mathrm{g} \mathrm{l}^{-1}\right)$ & 415 & 82 & 208 & 418 & 756 & 259 \\
\hline Chl- $a\left(\mu \mathrm{g} \mathrm{l}^{-1}\right)$ & 3,3 & 1,7 & 0,3 & 2,9 & 12,5 & 245 \\
\hline Phytoplankton biovolume $\left(\mathrm{mm}^{3} \mathrm{~m}^{-3}\right)$ & 797 & 752 & 27 & 437 & 3708 & 262 \\
\hline Zooplankton biomass (mg Dw $\left.\mathrm{m}^{-3}\right)$ & 26.5 & 16.3 & 2.5 & 22.4 & 97.7 & 217 \\
\hline Mysis relicta (ind. $\mathrm{m}^{-2}$ ) & 203 & 136 & 0 & 180 & 1019 & 232 \\
\hline Cisco, year class strength & 2.9 & 3.0 & 0 & 2.0 & 10 & 28 \\
\hline
\end{tabular}

was calculated for the $0-50 \mathrm{~m}$ depth interval. The cyclopoid copepod species Thermocyclops oithonoides and Mesocyclops leuckarti were not separated in the counting. However, based on irregular sampling tests $T$. oithonoides have been the dominant of the two species during the whole study period. The dry weights of different zooplankton species were calculated according to standard length-weight regressions (Bottrell et al. 1976). Phytoplankton biovolume (PB) and total chlorophyll- $a$ (Chl- $a$ ) were analysed in integrated samples from the 010 m layer. Phytoplankton was not sampled in 1974 and Chl- $a$ was only analysed from 1976 on. The phytoplankton samples were analysed according to methods described by Olrik et al. (1998). Chl- $a$ was measured spectrophotometrically after acetone extraction (Marker et al. 1980). Transparency was measured by use of standard Secchi disk. Epilimnion temperature (Temp) means the average temperature in the $0-10 \mathrm{~m}$ depth interval. Mysis relicta samples were collected by vertical net hauls (diameter $100 \mathrm{~cm}$, mesh size $200 \mu \mathrm{m}$ ) from $120 \mathrm{~m}$ to the surface. Population densities are given as ind $\mathrm{m}^{-2}$. Mysis was sampled in 1976 and in the period 1978-2000. In lack of more quantitative data we have used year class strength of cisco as an indicator of predation pressure from planktivorous fish. Each year class (1972-1999) were classified on a scale from 0 to 10 based on the relative proportion of the different year classes in gillnet catches (P. Aas and O. Hegge, pers. com.).

Arithmetic mean values of plankton biomass and environmental variables were calculated for the period from June $1^{\text {st }}$ to October $31^{\text {st }}$. Biomass data on 10 zooplankton species (as seasonal means, $\mathrm{mg} \mathrm{DW} \mathrm{m}^{-3}$ ) were used in ANOVA correlation analyses (Stat Graphics) with seasonal means of epilimnion temperature, trophic state indicators (PB, Chl-a), Mysis (ind $\mathrm{m}^{-2}$ ) and year class strength of cisco. In the correlation matrix variables were log-transformed to improve normality and reduce the influence of outliers.

\section{RESULTS}

\subsection{Temporal trends in environmental variables and plankton biomass}

Phytoplankton biovolume (PB) increased towards the mid 1970s, and PB and Chl- $a$ showed decreasing trends from the late 1970s to 2000 (Fig. 2). Apart from this general trend, the algal biomass was relatively high in the early 1980s and some years even in the 1990s (eg. 1991, 1992 and 1996). The transparency increased from $5-6 \mathrm{~m}$ in the $1970 \mathrm{~s}$ to $8-9 \mathrm{~m}$ in the $1990 \mathrm{~s}$ (mean values). Summer epilimnion mean temperature varied considerably from year to year especially in the late 1990s, but increased by approximately $1.5^{\circ} \mathrm{C}$ during the study period (from $\mathrm{ca} 10.5^{\circ} \mathrm{C}$ to $\mathrm{ca} 12.0^{\circ} \mathrm{C}$ ). Total zooplankton biomass increased during the 1970s, and showed a gradual decrease in the period 1978-2000. In 1973, 1988, 1992 and 1997 the year classes of cisco were very strong, whereas week or medium strong year classes were recorded most years in the 1970s and 1980s. Several year classes in the 1990 s were very week.

\subsection{Changes in zooplankton species composition and biomass}

The species composition of the crustacean zooplankton community was characterised by considerable stability of dominating species in the investigation period (Fig. 3). On average calanoids, cladocerans and cyclopoids made up $57 \%, 37 \%$ and $6 \%$ of the zooplankton biomass respectively. The seasonal mean biomass of the dominant calanoid, Eudiaptomus gracilis, showed substantial fluctuations with 6-7 years between tops, but a decreasing trend during the 1990s. Limnocalanus macrurus and Heterocope appendiculata biomasses were highest in the 1980s. Cyclops lacustris was more abundant in the 1970s than in the 1980s and 1990s, whereas Thermocyclops oithonoides/Mesocyclops leuckarti showed the opposite trend. Bosmina longispina and Daphnia galeata were dominant cladocerans most years. Both species had higher biomasses in the 1980s, when algal biomasses were still relatively high, than in later years. On the other hand, Daphnia cristata was more abundant some years in the period 1989-2000 than in earlier years. Holopedium gibberum reappeared in the early 1980 s with increasing biomass from 1984 to 1999, but was less abundant in 2000. The small cladoceran Bosmina longirostris was quite abundant in 1978 and 1993 (not shown in Fig. 3) but seemed to be of lesser importance the other years. The invertebrate predator Leptodora kindtii was relatively less abundant in the late 1990s than in earlier years. Bythotrephes longimanus, another cladoceran predator, was occasionally recorded during the whole period, but only in small numbers (not shown in Fig. 3). 

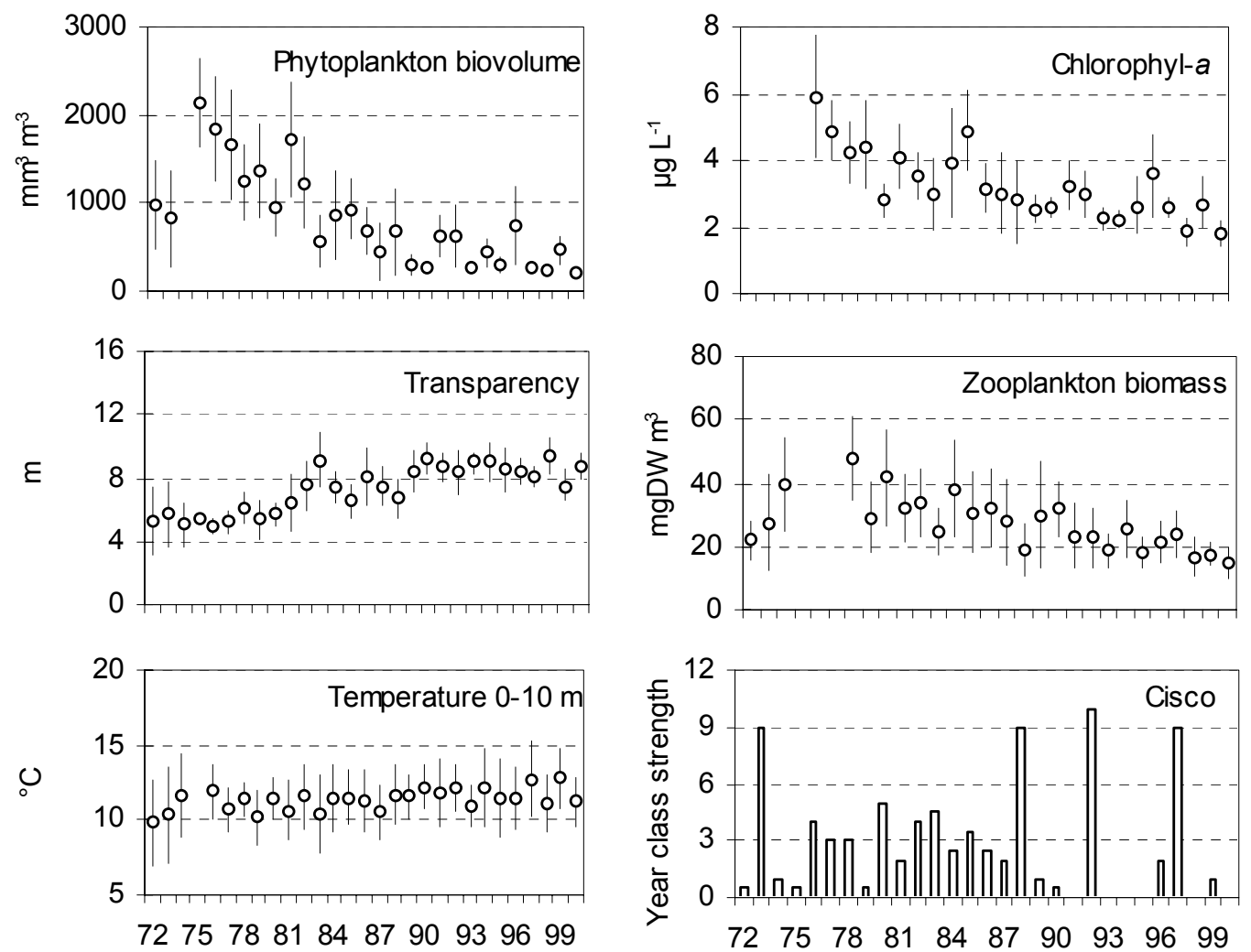

Fig. 2. Time series of phytoplankton biovolume, chlorophyll- $a$, Secchi disk transparency, crustacean zooplankton biomass, epilimnion temperature (seasonal means and $2 *$ standard errors) and year class strength of cisco (Coregonus albula) in Lake Mjøsa. Note that there are too few data to calculate seasonal means of several variables some years in the 1970 s and that cisco data from 2000 are missing.

\subsection{Correlations between environmental variables and zooplankton}

Seasonal means of zooplankton biomass (ZB) were significantly correlated with seasonal means of phytoplankton biovolume (PB, $p<0.01)$. There was also a significant positive correlation between seasonal means of Chl- $a$ and ZB $(p<0.01)$. ZB was not correlated to epilimnion temperature. The correlation matrix (Tab. 2) gives a summary of the correlations between environmental variables and the 10 most common crustacean zooplankton species in Lake Mjøsa. However, it must be stressed that a significant correlation between two variables only shows that there is a low probability that the relationship between the two variables were caused by chance. It is no evidence of a cause-effect relationship. Epilimnion temperature seemed to have a significant positive effect only on the biomass of $H$. gibberum, and no species were negatively correlated to temperature. A number of species (e.g., L. macrurus, C. lacustris, D. galeata and B. longispina) were positively correlated to trophic state variables (PB, Chl- $a$ or both), whereas $T$. oithonoides/M. leuckarti and $H$. gibberum were negatively correlated to PB and Chl- $a$. There was a weak, but significant positive correlation between cisco and the two most common cladocerans, D. galeata and
$B$. longispina. Neither did we find significant correlations between Mysis and any of the tested zooplankton species, nor between E. gracilis, D. cristata or L. kindtii and any of the environmental variables.

\section{DISCUSSION}

Our study has indicated a mainly bottom up regulation of the crustacean zooplankton biomass. Along with increasing algal biomass in the 1970s and subsequent decreasing algal biomass in the 1980s and 1990s, there was a parallel temporal trend in total crustacean zooplankton biomass. The total crustacean zooplankton biomass was probably to a large extent controlled by the amount of algae as concluded in an earlier study from the lake (Rognerud \& Kjellberg 1990). They found a significant correlation between zooplankton biomass and phytoplankton biovolume. However, the correlation was weak probably because of large fluctuations in the biomass of calanoids, which dominated the zooplankton biomass in most years. Thus, the total phytoplankton biovolume may serve as a rough indicator on the amount of food for herbivorous zooplankton as the abundance of edible algae (e.g. nanoplankton) and bacteria probably also increased along with increasing phytoplankton biovolume (Kjellberg et al. 2001). Other studies have also demonstrated significant positive cor- 

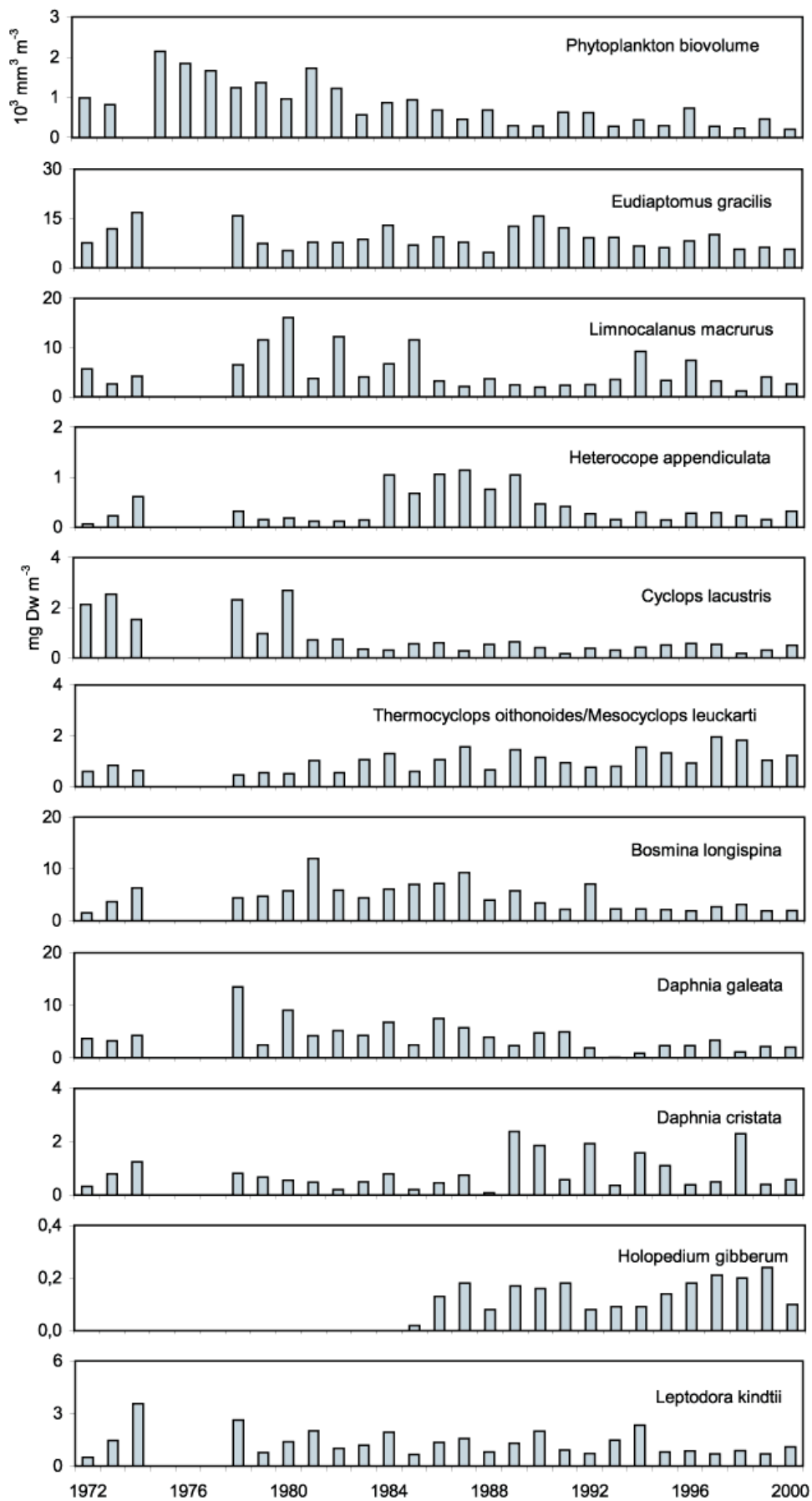

Fig. 3. Seasonal means of phytoplankton biovolume $\left(10^{3} \mathrm{~mm}^{3} \mathrm{~m}^{-3}\right)$ and biomass of the most common species of crustacean zooplankton $\left(\mathrm{mg} \mathrm{DW} \mathrm{m}^{-3}\right)$. Note that phytoplankton was not sampled in 1974, and that there are too few zooplankton data to calculate seasonal means in 1975, 1976 and 1977.

relations between phytoplankton biomass, lake productivity, and zooplankton biomass (McCauley \& Kalff 1981; Rognerud \& Kjellberg 1984; Pace 1986; Hessen et al. 1995a). The phytoplankton biomass seemed to be a decisive factor for the dominant herbivorous cladocerans $D$. galeata and B. longispina as well as for the omnivorous calanoid L. macrurus and cyclopoid C. lacustris. The decreases in these four species (and E. gracilis in the 1990s) were the main reason for the declining trend in total zooplankton biomass in later years. Thus, reduced algal biomass and probably also decreased concentration of edible algae are the most probable explanation to the declining total zooplankton biomass.

Limnocalamus macrurus and C. lacustris are both cold water species, and we speculate that they may have suffered from the warmer conditions in later years. 
Tab. 2. Correlation matrix for environmental variables and zooplankton biomasses. All variables except Temp and Chl- $a$ are logtransformed to improve normality (base 10). Significant correlations are bolded $(p<0.05)$. L. m. $=$ Limnocalanus macrurus; E. g. = Eudiaptomus gracilis; H. a. = Heterocope appendiculata; C. l. = Cyclops lacustris; T. M. = Thermocyclops oithonoides Mesocyclops leuckarti; D. g. = Daphnia galeata; D. c. = Daphnia cristata; B. l. = Bosmina longispina; H. g. = Holopedium gibberum; L. $k .=$ Leptodora kindtii.

\begin{tabular}{|c|c|c|c|c|c|c|c|c|c|c|c|c|c|c|c|c|}
\hline \multicolumn{2}{|c|}{ Variable } & \multirow{2}{*}{$\frac{\text { Temp }}{1.00}$} & \multirow[t]{2}{*}{ PB } & \multirow[t]{2}{*}{ Chl- $a$} & \multirow[t]{2}{*}{ Mysis } & \multirow[t]{2}{*}{ Cisco } & \multirow[t]{2}{*}{ L. $m$. } & \multirow[t]{2}{*}{ E. $g$. } & \multirow[t]{2}{*}{ H. $a$. } & \multirow[t]{2}{*}{ C. $l$. } & \multirow[t]{2}{*}{ T. M. } & \multirow[t]{2}{*}{ D. $g$. } & \multirow[t]{2}{*}{ D. c. } & \multirow[t]{2}{*}{ B. $l$. } & \multirow[t]{2}{*}{ H. $g}$. & \multirow[t]{2}{*}{ L. $k$. } \\
\hline Temp & ${ }^{\circ} \mathrm{C}$ & & & & & & & & & & & & & & & \\
\hline $\mathrm{PB}$ & $\mathrm{mm}^{3} \mathrm{~m}^{-3}$ & -0.28 & 1.00 & & & & & & & & & & & & & \\
\hline Chl- $a$ & $\mu \mathrm{g} \mathrm{l}^{-1}$ & -0.28 & 0.85 & 1.00 & & & & & & & & & & & & \\
\hline Mysis & ind $\mathrm{m}^{-2}$ & -0.22 & 0.32 & 0.16 & 1.00 & & & & & & & & & & & \\
\hline Cisco & year class str. & 0.17 & 0.43 & 0.34 & 0.44 & 1.00 & & & & & & & & & & \\
\hline L. $m$. & $\mathrm{mg} \mathrm{DW} \mathrm{m} \mathrm{m}^{-3}$ & -0.08 & 0.67 & 0.56 & 0.13 & 0.26 & 1.00 & & & & & & & & & \\
\hline E. $g$ & $\mathrm{mg} \mathrm{DW} \mathrm{m} \mathrm{m}^{-3}$ & 0.13 & 0.06 & 0.26 & 0.03 & 0.01 & -0.17 & 1.00 & & & & & & & & \\
\hline H. $a$. & $\mathrm{mg} \mathrm{DW} \mathrm{m} \mathrm{m}^{-3}$ & 0.11 & -0.13 & 0.05 & -0.16 & 0.14 & -0.24 & 0.31 & 1.00 & & & & & & & \\
\hline C. $l$. & $\mathrm{mg} \mathrm{DW} \mathrm{m} \mathrm{m}^{-3}$ & -0.11 & 0.52 & 0.37 & -0.13 & 0.36 & 0.63 & 0.00 & -0.17 & 1.00 & & & & & & \\
\hline T. M. & $\mathrm{mg} \mathrm{DW} \mathrm{m} \mathrm{m}^{-3}$ & 0.17 & -0.70 & -0.57 & -0.14 & -0.33 & -0.63 & 0.04 & 0.24 & -0.62 & 1.00 & & & & & \\
\hline D. $g$ & $\mathrm{mg} \mathrm{DW} \mathrm{m}$ & 0.02 & 0.51 & 0.43 & 0.14 & 0.47 & 0.18 & 0.24 & 0.29 & 0.43 & -0.22 & 1.00 & & & & \\
\hline D. $c$. & $\mathrm{mg} \mathrm{DW} \mathrm{m}$ & 0.07 & -0.41 & -0.35 & -0.13 & -0.40 & -0.41 & 0.35 & 0.06 & -0.16 & 0.48 & -0.10 & 1.00 & & & \\
\hline B. $l$. & $\mathrm{mg} \mathrm{DW} \mathrm{m}^{-3}$ & -0.39 & 0.57 & 0.51 & 0.31 & 0.51 & 0.14 & 0.14 & 0.29 & 0.29 & -0.23 & 0.45 & -0.04 & 1.00 & & \\
\hline H. $g$. & $\mathrm{mg} \mathrm{DW} \mathrm{m}^{-3}$ & 0.47 & -0.70 & -0.57 & -0.40 & -0.31 & -0.66 & 0.01 & 0.22 & -0.54 & 0.65 & -0.25 & 0.27 & -0.51 & 1.00 & \\
\hline L. $k$. & $\mathrm{mg} \mathrm{DW} \mathrm{m} \mathrm{m}^{-3}$ & -0.21 & 0.12 & -0.01 & -0.03 & -0.19 & 0.04 & 0.45 & 0.17 & 0.23 & 0.06 & 0.17 & 0.30 & 0.25 & -0.31 & 1.00 \\
\hline
\end{tabular}

However, no significant negative correlations with epilimnion temperature were found. Although, temperature can be an important variable, but the declining trend of these omnivorous species in later years is probably mainly caused by decreasing abundance of living and dead algae. Termocyclops oithonoides $/ M$. leuckarti showed the opposite trend with higher biomasses in years with low algal biomass. This is somewhat surprising, as both species are common even in eutrophic lakes, although high $\mathrm{pH}$ and eutrophic conditions probably favours $M$. leuckarti of the two species (reviewed by Nilssen \& Wärvågen 2000). Growth of young stages (nauplii) of cyclopoids can be severely hampered because of competition from cladocerans when the cladocerans dominate the plankton (Santher \& Lampert 1995; Winder et al. 2003). This could also have been the case in Lake Mjøsa during periods with high abundance of herbivores like $B$. longispina and especially $D$. galeata. Thus the temporal pattern of $T$. oithonoides/M. leuckarti can be explained by strong competition with cladocerans in periods with high algal biomass. Termocyclops oithonoides have been shown to survive high fish predation pressure better than $M$. leuckarti, and is therefore a more typical plankton species than the latter (Nilssen \& Wærvågen 2000). Both are warm water species and can respond to increasing water temperature by prolonging the active phase in the plankton and increasing population size (Gerten \& Adrian 2002). The population increase of $T$. oithonoides was probably caused by the early start of population growth in warm springs, whereas $M$. leuckarti seemed to respond to both elevated temperatures in spring and unusually warm conditions in mid-summer (Gerten \& Adrian 2002). However, the fact that the two species were treated together in our data set makes the interpretation difficult. Although the mean epilimnion temperature in Lake Mjøsa did not control the seasonal mean biomass, early warming of the lake can explain the population increase of $T$. oithonoides/M. leuckarti in later years. Reduced competition from $C$. lacustris may also be a possible explanation, but it seems not very likely as the two warm water species mostly occupies higher strata than $C$. lacustris in the ice-free season. High predation pressure from planktivorous fish on adult females with eggs has probably contributed to high mortality rates on M. leuckarti in some years (cf. Nilssen \& Wærvågen 2000). However, Kjellberg \& Sandlund (1983) found that T. oithonoides/M. leuckarti were not positively selected by planktivores in Lake Mjøsa.

The temporal trend in the Eudiaptomus gracilis population and lack of significant correlations with trophic state variables are consistent with earlier observations from Lake Mjøsa (Rognerud \& Kjellberg 1990). Lack of significant correlation between biomass of calanoids and lake trophy have also been shown in 12 lakes in Canada (Pace 1986). The positive correlation between E. gracilis and epilimnion temperature observed from 1972-88 in Lake Mjøsa (Rognerud \& Kjellberg 1990), disappeared when 12 more years were added in our study.

The long-term temporal trend of $H$. gibberum, as well as the highly significant negative correlation with PB and Chl- $a$, indicates a preference for oligotrophic conditions consistent with Pejler (1965) and Hessen et al. (1995a). The species disappeared in the 1960s, but reappeared in small numbers in the 1980s after a significant reduction in algal biomass and primary production (Rognerud \& Kjellberg 1990). Ambient Ca concentration has been shown as a key factor in regulating the distribution of $H$. gibberum and daphnids (Hessen et al. 1995b; Wærvågen et al. 2002). Because of their high Ca demands, species of Daphnia are supposed to be competitively disadvantaged in softwater lakes relative to less Ca-demanding species like $H$. gibberum. Our data from Lake Mjøsa does not contradict this, but 
rather suggest that high phytoplankton biomass and/or production can also affect $H$. gibberum abundance consistently. The positive correlation between epilimnion temperature and $H$. gibberum may indicate that this species has also taken benefit of higher epilimnion temperature in Lake Mjøsa. However, the population increase of $H$. gibberum took place in a period with both increasing epilimnion temperature and declining algal biomass. Thus, it is difficult to evaluate what was the most important factor. However, it is striking that $H$. gibberum disappeared during the eutrophication process, and reappeared when the algal biomass had been markedly reduced. This might have been caused by a negative impact of high concentrations of inedible algae or high $\mathrm{pH}(>8)$ in periods with high primary production (cf. Hessen et al. 1995b with references).

It is reasonable to assume that the positive correlations between $D$. galeata and B. longispina and year class strength of cisco are related to these two cladocerans being dominant food items for cisco. We hypothesised that year class strength of cisco could be used as an indicator of fish predation pressure, but this was obviously not the case. Instead, large biomasses of the two dominant cladocerans seemed to promote strong year classes of cisco, thus indicating a bottom up effect. The amount of available food during the early stages of development is most likely decisive for the year class strength of cisco. Our observations are in accordance with earlier observations that young of the year cisco in the lake probably rely almost exclusively on crustacean plankton and to a large extent on D. galeata and $B$. longispina (Kjellberg \& Sandlund 1983). Average body lengths of $D$. galeata and B. longispina (adult females with eggs) have varied within the ranges $1.0-1.3 \mathrm{~mm}$ and 0.5-0.6 mm respectively in most years (Kjellberg et al. 2001). These relatively small average body sizes are most likely caused by strong size-selective predation by planktivores (cf. Kjellberg \& Sandlund op. cit.; Sandlund et al. 1987). The relative success of $D$. galeata versus the smaller and less visible $D$. cristata is probably influenced by the intensity of predation by planktivorous fish, with $D$. galeata being the more vulnerable to high predation pressure (cf. Sandlund et al. 1987; Hessen et al. 1995a). Planktivorous fish may also affect cladoceran populations indirectly by controlling the abundance of invertebrate predators like Mysis relicta and Leptodora kindtii (Kjellberg et al. 1991; Rognerud \& Kjellberg 1990).

Daphnia galeata almost disappeared and other medium sized cladocerans (B. longispina, D. cristata) were observed in small numbers in 1993, the first year after a very strong year class of cisco hatched. On the other hand, another even smaller cladoceran (B. longirostris) was recorded in considerable numbers in contrast to most other years. It is reasonable to assume that this event was caused by intense predation by the large stock of $1^{+}$cisco. If so, the results indicate both top down and bottom up effects between planktivores and zooplankton. However, the low abundance of herbivores in 1993 did not cascade down to the phytoplankton level causing enhanced algal biomass as expected by the trophic cascade hypothesis (Carpenter et al. 1987). PB and Chl-a concentrations were very low in 1993, thus suggesting a primarily bottom up regulation of the phytoplankton level in Lake Mjøsa.

\section{CONCLUSIONS}

The eutrophication and subsequent oligotrophication of Lake Mjøsa affected zooplankton biomass and species composition considerably. Several crustacean zooplankton species were clearly negatively affected by reduced algal biomass, whereas a few species seemed to show a positive response. The data from the monitoring also indicated influence between other time-dependent factors like epilimnion temperature, planktivorous fish and zooplankton, although some of the effects were contrary to what we had expected. Our study emphasises the importance of bottom up forces for the temporal changes in zooplankton community structure and for the success of planktivorous fish populations. However, it also indicated top down control on dominant cladocerans in years with especially strong year classes of cisco and competitive interactions between cladocerans and cyclopoide copepods. This underlines the complexity of factors and processes that affect changes in zooplankton species composition and biomass. The ongoing monitoring program can serve as a useful tool for the local, regional and national environment authorities also in the future, in order to prevent a new eutrophication process to emerge and for assessing other environmental impacts like climate change and effects of micro pollutants.

\section{ACKNOWLEDGMENTS}

We thank Per Aas and Ola Hegge for information on year class strength of cisco, Pål Brettum for the phytoplankton analyses, Gerd Justås for assistance with the zooplankton analyses and Mette-Gun Nordheim for preparing the statistics. We also thank Sigurd Rognerud for helpful comments on earlier versions of the manuscript.

\section{REFERENCES}

Bottrell, H.H., A. Duncan, Z.M. Gliwicz, E. Grygierek, A. Herzig, A. Hillbricht-Ilkowska, H. Kurasawa, P. Larsson \& T. Weglenska. 1976. A review of some problems in zooplankton production studies. Norw. J. Zool., 24: 419456.

Carpenter, S.R., J.F. Kitchell, J.R. Hodgson, P.A. Cochran, J.J. Elser, M.M. Elser, D.M. Lodge, D. Kretchmer, X. He \& C.N. von Ende. 1987. Regulation of lake primary production by food web structure. Ecology, 68: 1863-1876.

Edmondson, W.T \& A.H. Litt. 1982. Daphnia in Lake Washington. Limnol. Oceanogr., 27: 272-293.

Einsle, U. 1978. Qualitative und quantitative Änderungen im Crustaceenplankton des Bodensee-Obersees. Arch. Hydrobiol., 82: 300-315. 
Gerten, D. \& R. Adrian. 2002. Species-specific changes in the phenology and peak abundance of freshwater copepods in response to warm summers. Freshwat. Biol., 47: 21632173.

Hessen, D.O., B.A. Faafeng \& T. Andersen. 1995a. Replacement of herbivore zooplankton species along gradients of ecosystem productivity and fish predation pressure. Can. J. Fish. Aquat. Sci., 52: 733-742.

Hessen, D.O., B.A. Faafeng \& T. Andersen. 1995b. Competition or niche segregation between Holopedium and Daphnia; empirical light on abiotic key parameters. Hydrobiologia, 307: 253-261.

Holtan, H. 1979. The Lake Mjøsa story. Arc. Hydrobiol. Beih., 13: $242-258$.

Holtan, H. 1993. The results of the 20-years battle against eutrophication in Lake Mjøsa. Contribution at the EWPCAISWA Syposium in München, May 11-14.1993: 371-382.

Huitfeldt-Kaas, H. 1906. Planktonundersøkelser $i$ Norske Vande. Christiania: 199 pp. (In Norwegian).

Kjellberg, G. \& O.T. Sandlund. 1983. Nceringsrelasjoner $i$ Mjøsas pelagiske økosystem. DVF - Mjøsundersøkelsen. Report 6: 61 pp. (In Norwegian).

Kjellberg, G., D.O. Hessen \& J.P. Nilssen. 1991. Life history, growth and production of Mysis relicta in the large, fjordtype Lake Mjøsa, Norway. Freshwat. Biol., 26: 165-173.

Kjellberg, G., O. Hegge \& J.E. Løvik. 2001. Tiltaksorientert overvåking av Mjøsa med tilløpselver. NIVA report, 43642001: 129 pp. (In Norwegian).

Manca, M. \& D. Ruggio. 1998. Consequences of pelagic foodweb changes during a long-term lake oligotrophication process. Limnol. Oceanogr., 43: 1368-1373.

McCauley, E. \& J. Kalff. 1981. Empirical relationships between phytoplankton and zooplankton biomass in lakes. Can. J. Fish. Aquat. Sci., 38: 458-463.

Marker, A.H.F., E.A. Nusch, H. Rai \& B. Riemann. 1980. The measurement of photosynthetic pigments in freshwaters and standardization of methods: Conclusions and recommendations. Arch. Hydrobiol., Beih. Ergebn. Limnol., 14: 91-106.

Nilssen, J.P. \& S.B. Wærvågen. 2000. Superficial ecosystem similarities vs autecological stripping: the "twin species"
Mesocyclops leuckarti (Claus) and Thermocyclops oithonoides (Sars) - seasonal habitat utilisation and life history traits. J. Limnol., 59: 79-102.

Olrik, K., P. Blomqvist, P. Brettum, G. Cronberg \& P. Eloranta. 1998. Methods for quantitative assessment of phytoplankton in freshwaters part I: sampling, processing and application in freshwater environmental monitoring programs. Naturvårdsverket report 4860. Stockholm: 86 pp.

Pace, M.L. 1986. An empirical analysis of zooplankton community size structure across lake trophic gradients. Limnol. Oceanogr., 31: 45-55.

Pejler, B. 1965. Regional-ecological studies of Swedish freshwater zooplankton. Zool. Bidr. Uppsala, 36: 407-515.

Rognerud, S. \& G. Kjellberg. 1984. Relationships between phytoplankton and zooplankton biomass in large lakes. Verh. int. Ver. Limnol., 22: 666-671.

Rognerud, S. \& G. Kjellberg. 1990. Long-term dynamics of the zooplankton community in Lake Mjøsa, the largest lake in Norway. Verh. int. Ver. Limnol., 24: 580-585.

Sandlund, O.T., T.F. Næsje \& G. Kjellberg. 1987. The size selection of Bosmina longispina and Daphnia galeata by co-occuring cisco (Coregonus albula), whitefish ( $C$. lavaretus) and smelt (Osmerus eperlanus). Arch. Hydrobiol., 110: 357-363.

Santer, B. \& W. Lampert. 1995. Summer diapause in cyclopoid copepods: adaptive response to a food bottleneck? J. Anim. Ecol., 64: 600-613.

Schindler, D.W. 1987. Detecting ecosystem responses to anthropogenic stress. Can. J. Fish. Aquat. Sci., 44: 6-25.

Wallin, M., B. Andersson, R. Johnson, H. Kvarnäs, G. Persson, G. Weyhenmeyer \& E. Willén. 2000. Mälaren. Miljötilstånd och utvekling 1965-98. Sveriges Landbruksuniversitet, Uppsala: 94 pp. (In Swedish).

Winder, W., H.R. Bürgi \& P. Spaak. 2003. Mechanisms regulating zooplankton populations in a high-mountain lake. Freshwat. Biol., 48: 795-809.

Wærvågen, S.B., N.A. Rukke \& D. O. Hessen. 2002. Calcium content of crustacean zooplankton and its potential role in species distribution. Freshwat. Biol., 47: 1866-1878. 